\title{
More about the lion and its claw
}

SIR-Faulkner's letter' on the translation of the famous phrase "tanquam ex ungue leonem" (I recognize the lion by its claw), said to have been uttered by John Bernoulli about a work of Newton's, can be bolstered by appeal to older sources. I have a Latin dictionary published in Cambridge in 1693, Linguae Romanae Dictionarium Luculentum Novum, A New Dictionary in Five Alphabets. It is not impossible that this is the very dictionary that Newton himself consulted when he sought to probe the nuances of Bernoulli's remark. Here I find, in the relevent one of the five sections, "Unguis, . . . A nail of the fingers or toes in man, bird or beast; a claw, a talon: also the hoof of an ox or cow

"Thus there are grounds here for preferring, as Faulkner does, "claw" for "paw" and the following word in this dictionary could suggest that "ungue" could have an active connotation as well: "Ungula . . The hoof of an horse or other beast: also an hook that is used for the drawing out of a child that is dead in the mother's womb; a tormenting iron, wherewith the sides of malefactors were pinched or burnt." Thus Newton's view of the phrase may well have been like Faulkner's, that Bernoulli knew he had been burned!

The letter does suffer from two obvious errors, however. The title ("Darwin's "claw", not "paw"!") is a howler, but more revealing about Nature's copyeditors than the letter's author. I suppose there are some dimensions (other than length of name) where it would be proper to equate Darwin with Newton, but surely not in the realm of quotation. The second grievous error is more common, and may be worth attempting a public correction. To misspell Bernoulli as the letter does, with an extra "i" ("Bernouilli"), is not only an affront to the largest important clan in the history of the mathematical sciences, but to the memory of one of the greatest scholars and writers in the pantheon of creative mathematicians. I offer the following quotation from an article about the mathematician Augustus De Morgan, in the original Palgrave.?

He has lost the sight of one eye in infancy. The strain upon the remaining eye, involved by his constant industry in accumulating stores of knowledge, must have been severe. The writer once had occasion, in the letter to him, to mention one of the Bernoulli family of mathematicians of the last century, and spelt the name wrongly, that is with two i's, Bernouilli. "Oh," replied De Morgan, "you have deeply offended me. Pray always keep in mind the personal interest I take in

Letters submitted for Correspondence should be typed, double-spaced, on one side of the paper only. one-eyed philosophers."

Department of Statistics,

Stephen M. Stigler

University of Chicago,

5734 University Avenue,

Chicago,

Illinois 60637, USA

1. Faulkner, J. Nature 332, 200 (1988).

2. Palgrave, R. H. I. (ed.) Dictionary of Political Economy, 2 , 820 (Macmillan, London, 1896).

SIR-As master of the college in which Newton lived and worked for the greater part of his life, I was intrigued by the speculations of John Faulkner (Nature 332, 200; 1988) on possible meanings to be read into the phase "ex ungue leonem" used by Bernoulli about Newton's solution of the brachystochrone problem that he had set as a challenge. I did however remain sceptical because it seemed to me at least possible that the phrase was merely a tag from some classical author, familiar to educated people three centuries ago but no longer current; a pointer in this direction was that "ex ungue leonem" scans as the end of an epic or elegiac hexameter. I therefore looked for it in concordances of Horace, Virgil, Ovid, Juvenal and Catullus, but without success. I next asked for help from my friend and colleague, E.W. Handley, Regius Professor of Greek and Fellow of this college, and he promptly found the solution, which he set out in the following letter to me:

\section{Dear Andrew,}

Thank you for letting me in on the intriguing little problem of the lion's claw.

Bernoulli is alluding to a proverbial phrase, as you suggest. Faulkner's interpretation seems to me improbable in itself; and I would share your view that the presence of the allusion is against it; for while one can twist a proverb, one would want a much clearer sign from the context than we have in order to suppose that that is being done here.

The proverb is Greek in origin, and is one of a number which relate to popular experiences of inference. 'Painting' or 'recognizing' the lion from its claw (or claws) means basically that if you have that bit (or those bits) you can tell that it came from an animal of a certain kind and size: a single sample of Newton's work makes it possible to be clear what kind and size of a mathematician he is.

In detail (as often happens) the story is more intricate. Like you, I began by looking for a Latin tag from the end of a hexameter, or a proverb in the traditional form of a paroemiac, which metrically comes to the same thing, but does not require one to postulate a poem. But there is no trace of such a proverb in the standard work on the subject, Otto's Sprichwörter der Römer (1890), nor indeed in the list of 'lion' proverbs in the Thesaurus Linguae Latinae s.v. leo; though I am bound to say that I was somewhat relieved that you had checked the likely poets in modern concordances. This is a dead end, so far as I can see.

In Greek the story is different. Various dif- ferent treatises in the Corpus Paroemio-

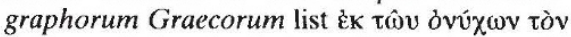

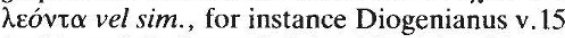
(vol.i, p.252 Leutsch-Schneidewin) with an explanation like the one given above; and from the editors' notes there one gathers that the earliest attestation is in Alcaeus (vii-vi B.C.) as quoted by Plutarch, de defectu oraculorum 3 (Moralia $410 \mathrm{C}$ ). It might well be that that is Bernoulli's source. I had wondered about Erasmus, Adagia or a derivative, but at Adagia 834 (I.ix.34) E. offers ex unguibus aestimare leonem as his version of the Greek, with plural claws; while Plutarch gives us both the singular 'claw' and a work with some mathematical content which might have made it memorable to Bernoulli - but the Moralia were in any case quite widely read at the time. It is also true that the standard Latin translation of Plutarch's phase produces - by literal means - ex ungue leonem out of $\dot{\varepsilon} \xi \dot{\delta} v v \chi o \zeta \tau o v \lambda \varepsilon \delta$ ó $\tau \alpha$, thus creating the appearance of a tag or proberb in Latin which led to our wild goose chase.

Yours sincerely,

(sgd) Eric Handley

I am most grateful to Professor Handley

for searching out this solution to the problem, and for allowing me to publish his letter.

The Master's Lodge,

Trinity College,

Cambridge CB2 1TQ, UK

SiR-John Faulkner ${ }^{1}$ interpreted the Latin phrase "tamquam ex ungue leonem" as a sign of contempt, "the old lion has given me the finger". The old lion would be Isaac Newton, the person that made the remark Johann Bernoulli.

Fortunately, Bernoulli knew his classics better than Faulkner, for the well-known phrase "ex ungue leonem" is a quotation from the Greek poet Alcaeus ${ }^{2}$. This phrase was made more or less famous by the Dutch humanist Erasmus who, in his Adagia (Proverbs), quoted it as leonem ex unguibus aestimare': 'to judge the lion by the claws', that is, by a slight but characteristic mark.

Erasmus had some doubt about the source of this proverb. In my opinion this is why other books of quotation do not mention it. Among humanists this phrase was well-known. I myself discovered it for instance in the Apotheosis of Macropedius (1565), a poem by Macropedius' pupil Vladeraccus ${ }^{3}$. No contempt, no visceral feelings, but admiration. Quoting such a phrase, Bernoulli showed his admiration: "You shall know Newton by his fruits".

JAN BLOEMENDAL

Bachlaan 27,

3781 HC Voorthuizen,

The Netherlands

1. Nature 332, 200 (1988)

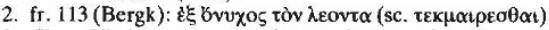

3. Chr. Vladeraccus, Apotheosis Macropedii, vss. $145 \mathrm{ff}$ Unquibus ut magni magna virtute leones Noscuntur, volucres prodit et ipse color, Sic quoque discipuli monstrant virtute magistrum. . .' 'As great lions with great courage are known by their claws and as their colour betrays the birds, so do his pupils by their virtue show the master.' 